\title{
Thermal state of the active layer and permafrost along the Qinghai-Xizang (Tibet) Railway from 2006 to 2010
}

\author{
Q. Wu ${ }^{1}$, T. Zhang ${ }^{2,3}$, and Y. Liu ${ }^{1}$ \\ ${ }^{1}$ State Key Laboratory of Frozen Soil Engineering, Cold and Arid Regions Environmental and Engineering Research \\ Institute, Lanzhou, 730000, China \\ ${ }^{2}$ MOE Key Laboratory of West China's Environment System, Lanzhou University, Lanzhou, 730000, China \\ ${ }^{3}$ National Snow and Ice Data Center, Cooperative Institute for Research in Environmental Sciences, University of Colorado, \\ Boulder, Colorado, USA
}

Correspondence to: T. Zhang (tzhang@ @ nsidc.org)

Received: 31 May 2011 - Published in The Cryosphere Discuss.: 22 September 2011

Revised: 26 March 2012 - Accepted: 26 March 2012 - Published: 31 May 2012

\begin{abstract}
In this study, we investigated changes in active layer thickness (ALT) and permafrost temperatures at different depths using data from the permafrost monitoring network along the Qinghai-Xizang (Tibet) Railway (QXR) since 2005. Among these sites, mean ALT is $\sim 3.1 \mathrm{~m}$, with a range of $\sim 1.1$ to $5.9 \mathrm{~m}$. From 2006 through 2010, ALT has increased at a rate of $\sim 6.3 \mathrm{~cm} \mathrm{a}^{-1}$. The mean rate of permafrost temperature rise at the depth of $6.0 \mathrm{~m}$ is $\sim 0.02^{\circ} \mathrm{Ca}^{-1}$, estimated by linear regression using $5 \mathrm{yr}$ of data, and the mean rate of mean annual ground temperature (MAGT) rise at a depth of zero amplitude is $\sim 0.012{ }^{\circ} \mathrm{Ca}^{-1}$. Changes for colder permafrost (MAGT $<$ $-1.0^{\circ} \mathrm{C}$ ) are greater than changes for relatively warmer permafrost (MAGT $>-1.0^{\circ} \mathrm{C}$ ). This is consistent with results observed in the Arctic and subarctic.
\end{abstract}

\section{Introduction}

Qinghai-Xizang (Tibet) Plateau (QXP), with an average elevation of more than $4000 \mathrm{~m}$ above sea level (a.s.l.), is the highest and the most extensive plateau in the world (Liu and Chen, 2000) and is known as "roof of the world". Permafrost area on the Plateau is estimated at $\sim 1.3 \times 10^{6} \mathrm{~km}^{2}$ (Nan, 2005), approximately $70.6 \%$ of the land area of the QXP (Zhou et al., 2000). Although permafrost areas in the QXP make up only $\sim 5.7 \%$ of the $22.79 \times 10^{6} \mathrm{~km}^{2}$ of permafrost in the Northern Hemisphere (Zhang et al., 1999), it is estimated that China contains the largest mountain permafrost area in the Northern Hemisphere (Zhang et al., 2003). Zhao et al. (2010) synthetically analyzed the thermal state of the active layer and permafrost in Central Asia, including the QXP, as part of the International Permafrost Association's (IPA) International Polar Year (IPY) project Thermal State of Permafrost (TSP). This study is an additional contribution to the IPA's IPY project in studying changes in the thermal state of permafrost and active layer thickness (ALT) in the QXP. In previous studies, we investigated changes in soil temperature within the active layer, the permafrost temperature at $6.0 \mathrm{~m}$ depth from 1996 to 2006 (Wu and Zhang, 2008), and ALT from 1995 to 2007 (Wu and Zhang, 2010) along the Qinghai-Xizang (Tibet) Highway (QXH). Due to the construction of the Qinghai-Xizang Railway (QXR), most of these study sites were terminated. All of these sites were relatively shallow, usually $\sim 6-8 \mathrm{~m}$ in depth. A new permafrost monitoring network was established in 2005 along the QXR with 27 sites, and borehole depths are greater than $15 \mathrm{~m}$. This study therefore analyzes variation of ALT, permafrost temperatures at $6.0 \mathrm{~m}$ depth, and mean annual ground temperature (MAGT), defined as permafrost temperature at a depth of zero annual amplitude, during the period of 2006-2010 using data from these new sites. This study is complementary to previous studies and contributes to the understanding of the thermal state of permafrost and the active layer on the QXP during the third International Polar Years. 
Table 1. Geographical data and information on the 27 sites along the QXR from 2006 to 2010.

\begin{tabular}{|c|c|c|c|c|c|c|c|c|c|c|c|}
\hline \multirow[t]{2}{*}{ Area } & \multirow[t]{2}{*}{$\begin{array}{l}\text { Site } \\
\text { name }\end{array}$} & \multicolumn{2}{|c|}{ Location } & \multirow[t]{2}{*}{ Elevation (m) } & \multirow[t]{2}{*}{ Soil Type } & \multirow[t]{2}{*}{$\begin{array}{l}\text { Vegetation } \\
\text { Cover }(\%)\end{array}$} & \multirow[t]{2}{*}{ Ecosystem } & \multirow{2}{*}{$\begin{array}{l}\text { MAAT }\left({ }^{\circ} \mathrm{C}\right) \\
\text { (Date of) } \\
\text { measurement }\end{array}$} & \multirow[t]{2}{*}{$\begin{array}{l}\text { Active layer } \\
\text { thickness (m) }\end{array}$} & \multirow[t]{2}{*}{$\begin{array}{l}\text { MAGT at depth of } \\
12 \text { to } 15 \mathrm{~m}\left({ }^{\circ} \mathrm{C}\right)\end{array}$} & \multirow[t]{2}{*}{$\begin{array}{l}\text { Disturbance } \\
\text { extent }\end{array}$} \\
\hline & & Longitude, $^{\circ}$ & Latitude, $^{\circ}$ & & & & & & & & \\
\hline \multirow{2}{*}{$\begin{array}{l}\text { Kunlun Mts. } \\
\text { Budongquan }\end{array}$} & KM2 & 94.0515 & 35.6210 & 4757 & clay & 47 & sandy grassland & - & 1.83 & -3.04 & no \\
\hline & BD1 & 93.9633 & 35.6171 & 4636 & sandy loam & 8 & sandy grassland & - & 2.47 & -0.60 & no \\
\hline \multirow{4}{*}{$\begin{array}{l}\text { Chumaer River } \\
\text { High Plain }\end{array}$} & $\mathrm{CM} 3$ & 93.9633 & 35.5518 & 4547 & sandy clay & 24 & \multirow[t]{4}{*}{ sandy grassland } & \multirow[t]{4}{*}{-4.6 (Zhao, 2004) } & 1.06 & -1.20 & with small puddle \\
\hline & CM5 & 93.4465 & 35.3640 & 4507 & clay with gravel & 26 & & & 2.84 & -1.20 & with small puddle \\
\hline & CM6 & 93.446 & 35.3636 & 4504 & clay with gravel & 17 & & & 3.06 & -0.95 & No \\
\hline & CM7 & 93.2218 & 35.2774 & 4589 & sandy clay & 17 & & & 4.80 & -0.41 & No \\
\hline \multirow[t]{2}{*}{ Kekexili Mts. } & WD3 & 93.1106 & 35.2044 & 4613 & sandy clay & 88 & \multirow[t]{2}{*}{ alpine meadow } & \multirow[t]{2}{*}{$-5.08(2008)$} & 1.93 & -1.53 & No \\
\hline & WD4 & 93.0420 & 35.1384 & 4734 & & 37 & & & 0.92 & -2.56 & No \\
\hline $\begin{array}{l}\text { Hongliang } \\
\text { River Basin }\end{array}$ & HR3 & 93.0292 & 35.0691 & 4675 & sand & 23 & sandy grassland & $-4.37(2008)$ & 2.36 & -1.11 & No \\
\hline \multirow[t]{2}{*}{ Fenghuo Mts. } & FH2 & 92.8986 & 34.6724 & 4894 & sandy clay & 67 & \multirow{2}{*}{$\begin{array}{l}\text { alpine meadow } \\
\text { sandy grassland }\end{array}$} & \multirow{2}{*}{$-5.4(2005)$} & 1.76 & -2.02 & \multirow{2}{*}{$\begin{array}{l}\text { Slight } \\
\text { No }\end{array}$} \\
\hline & $\mathrm{FH} 3$ & 92.7823 & 34.6104 & 4715 & sandy clay & 60 & & & 4.01 & -0.65 & \\
\hline \multirow{2}{*}{$\begin{array}{l}\text { Yamaer River } \\
\text { Basin }\end{array}$} & YM1 & 92.7438 & 34.5757 & 4654 & clay & 23 & sandy grassland & - & 3.32 & -0.39 & no \\
\hline & YM2 & 92.7307 & 34.5283 & 4616 & sand & 18 & & & 5.86 & -0.25 & slight \\
\hline Wuli Basin & WL1 & 92.7260 & 34.4816 & 4587 & sandy clay & 25 & alpine meadow & -3.8 (Zhao, 2004) & 3.09 & -0.63 & no \\
\hline Tuotuo & TT1 & 92.23 & 33.88 & 4640 & sandy loam & 44 & sandy grassland & $-2.4(2005)$ & 2.60 & -0.33 & No \\
\hline River basin & TT2 & 92.20 & 33.76 & 4647 & gravel & 4 & & & & 0.16 & No \\
\hline Kaixinling & KL1 & 92.3399 & 34.0113 & 4672 & sandy clay & 23 & alpine grassland & $-3.4(2008)$ & 2.40 & -0.69 & no \\
\hline Basin & KL3 & 92.3398 & 33.9558 & 4622 & sandy & 22 & sandy grass land & & 2.83 & -0.72 & \\
\hline & KL5 & 92.3417 & 33.9379 & 4622 & sandy loam & 19 & sandy grassland & & 3.38 & -0.60 & with small puddle \\
\hline Wengquan & WQ1 & 91.9394 & 33.4687 & 4778 & sandy clay & 13 & alpine grassland & - & 4.65 & -0.09 & No \\
\hline Basin & WQ2 & 91.9459 & 33.3979 & 4817 & sandy clay & 9 & sandy grassland & & 3.36 & -0.32 & No \\
\hline Tanggula Mts. & TG2 & 91.8749 & 33.3037 & 4841 & sandy clay & 2 & sandy grassland & $-3.08(2008)$ & 4.99 & 0.71 & \\
\hline & TG3 & 91.8040 & 33.0887 & 4926 & sandy loam & 41 & alpine grassland & & 4.56 & 0.27 & with small puddle \\
\hline & TG4 & 91.7525 & 33.0715 & 4974 & sandy loam & 88 & alpine wetland & & 2.77 & -1.15 & No \\
\hline Zajiazangbu & TJ1 & 91.5341 & 32.5078 & 4868 & sand & 19 & sandy grassland & - & 3.50 & -0.06 & No \\
\hline River Basin & $\mathrm{TJ} 2$ & 91.6205 & 32.3948 & 4887 & sand & 31 & sandy grassland & & 3.42 & -0.08 & No \\
\hline Anduo Basin & $\mathrm{AD} 2$ & 91.5815 & 32.3095 & 4814 & sandy clay & 88 & alpine meadow & $-1.68(2005)$ & 2.37 & -0.08 & No \\
\hline
\end{tabular}

MAGT is mean annual ground temperature. MAAT is mean annual air temperature.

\section{Data and methods}

The data used in this study include soil temperatures measured along the QXH in 1995/1998, and along the QXR in 2005. During the construction of the QXR from 2001-2006, 43 monitoring sites and three weather stations were established to detect changes in the thermal state of permafrost beneath the embankment, monitoring embankment stability (Wu et al., 2008). Although the main objective of these 43 sites is to monitor the thermal state of permafrost under the railway embankment, 27 sites away from the embankment under the natural surface ( $\sim 30-80 \mathrm{~m}$ away from the centerline of the embankment) were also established and monitored to study the effect of climate change on permafrost (Fig. 1; Wu et al., 2008). Data from these monitoring sites have been reported by $\mathrm{Wu}$ and Liu (2004) and Wu and Zhang (2008, 2010).

Because the environment and the surface conditions outside of the QXR embankment were protected during the construction period, we believe that these sites have not been impacted by the railway construction and operation during the past $10 \mathrm{yr}$. We conducted a comprehensive survey of surface conditions around these sites in September 2011 and found that the surface conditions beyond the embankment remain in their the original state compared with those several hundred meters away from the railway. We believe the surface disturbance by the railway is minimal and negligible. Long-term monitoring and further studies are certainly needed. Our study used soil temperature data from these 27 non-embankment sites to analyze the change in ALT and the thermal state of permafrost from 2005 to 2010 .

\subsection{Site description}

The 27 monitoring sites along the $542 \mathrm{~km}$ of the QXR, from Xidatan to Anduo, span $\sim 3.4^{\circ}$ latitude and $\sim 2.6^{\circ}$ longitude (Fig. 1). The elevation of these sites varies from $4500 \mathrm{~m}$ a.s.l. at Chumaer River high-plain sites to $4970 \mathrm{~m}$ a.s.l. at the Tanggula Mountain site, with a mean elevation of $\sim 4710 \mathrm{~m}$ a.s.1. These sites are distributed in various terrain, including high-altitude mountains, high plains, and basins from north to south of the Plateau. In the high-elevation mountains along the QTR (the Kunlun Mountains, Kekexili Mountains, Fenghuo Mountains, and Tanggula Mountains), the MAGTs are lower than $-1.0^{\circ} \mathrm{C}$ or $-2.0^{\circ} \mathrm{C}$, the ALT ranges from $1.2 \mathrm{~m}$ to $2.0 \mathrm{~m}$, the permafrost thickness is greater than $60 \mathrm{~m}$ (Wu et al., 2010), and ice-rich permafrost exists from the permafrost table down to $10 \mathrm{~m}$ below the ground surface. In the high plain along the QTR (the high plain of the Chumaer River), the MAGTs range from $-0.5^{\circ} \mathrm{C}$ to $-1.5^{\circ} \mathrm{C}$, the ALT ranges from $2.0 \mathrm{~m}$ to $3.0 \mathrm{~m}$, the permafrost thickness is less than $50 \mathrm{~m}$ (Wu et al., 2010), and ice-rich permafrost 


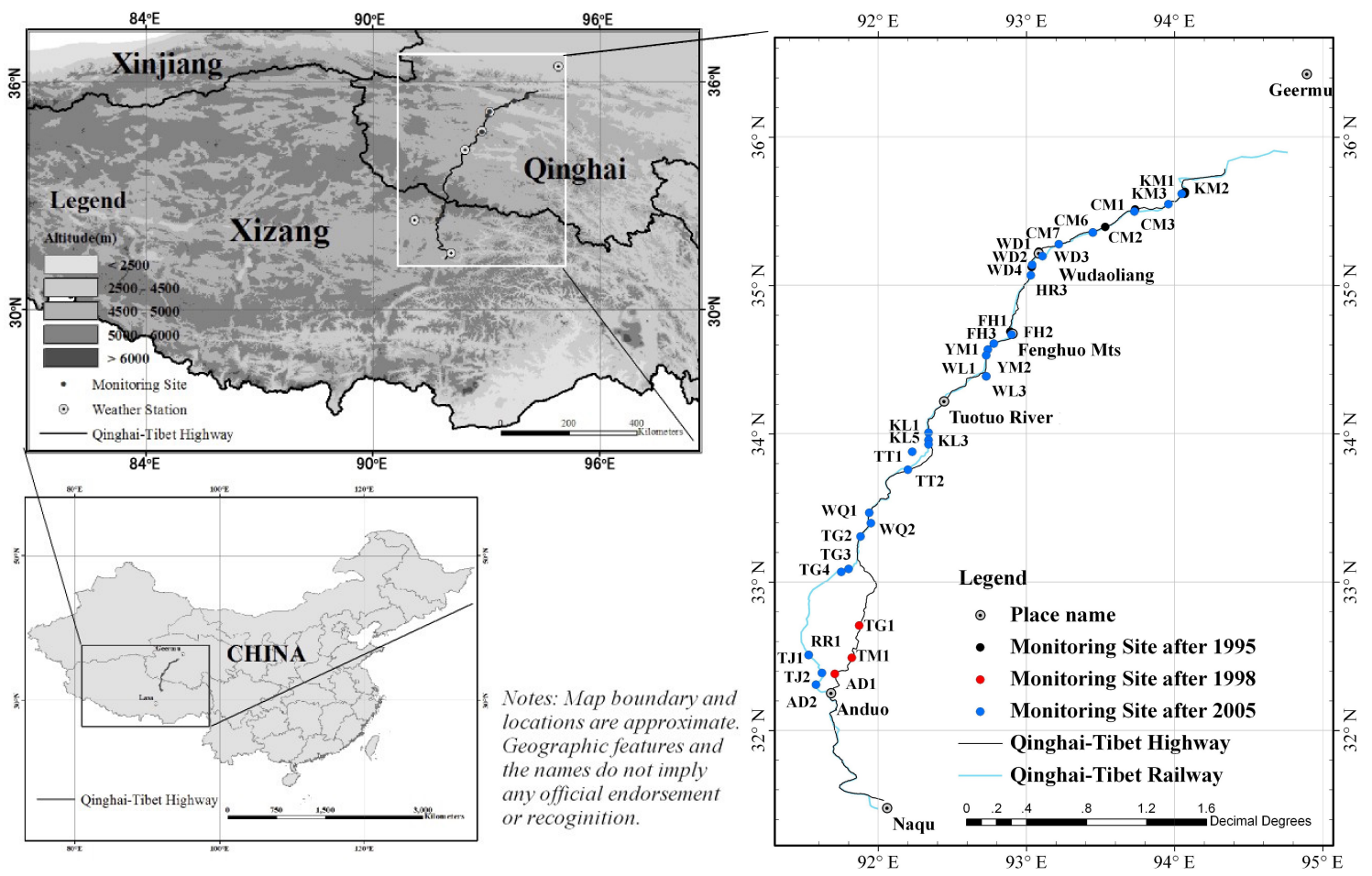

Fig. 1. Monitoring network along the Qinghai-Xizang (Tibet) Railway and Highway.

is widespread from the permafrost table to $10 \mathrm{~m}$ below the ground surface. In the basins along the QTR (the Beilu River, Yamer River, Wuli, Tuotuo River, Kaixinling, Zajiazangbu River, and Anduo), the MAGTs are higher than $-0.5^{\circ} \mathrm{C}$ (but some are much lower than $-0.5^{\circ} \mathrm{C}$ ), most of the ALT is greater than $3 \mathrm{~m}$ (but some is exceptionally lower than $2.5 \mathrm{~m}$ ), permafrost thickness ranges from $10 \mathrm{~m}$ to $25 \mathrm{~m}$, and thawed areas are widespread. Geographical data and information about the 27 QXR sites are listed in Table 1. There are few weather data from the QXR; therefore, the air-temperature data in Table 1 were measured in different years. Ecosystem, vegetation and engineering disturbance for all sites were surveyed in situ in September 2011.

\subsection{Soil temperature measurements}

The use of thermistor strings to measure soil temperature has been widely accepted since 1982 (Cheng, 1980), and such strings have been used in the QXP region since the 1990s by the Chinese State Key Laboratory of Frozen soil Engineering (SKLFSE). They are currently used to monitor permafrost temperature along the QXR (Sheng et al., 2002; Zhao et al., 2004; Cheng, 2005, 2007; Zhang et al., 2008; Wu and Zhang, 2008; Zhao et al., 2010).

In this study, soil temperature was measured from 0 to $20 \mathrm{~m}$ deep at all sites with string of thermistors at depths of $5,20,40,80,120,160$, and $200 \mathrm{~cm}$ from the surface to $2 \mathrm{~m}$ deep; $0.5 \mathrm{~m}$ intervals from $2 \mathrm{~m}$ to $10 \mathrm{~m}$ deep; and
$1 \mathrm{~m}$ intervals from $10 \mathrm{~m}$ to $20 \mathrm{~m}$ deep, including 33 thermistors. The thermistors were made by the SKLFSE, and their laboratory temperature accuracy is $\pm 0.05^{\circ} \mathrm{C}$. In-situ measurements were automatically collected by a data logger (CR3000, made by Campbell Co., USA), at 10:00 a.m. Beijing Standard Time each day.

\subsection{Methods}

We analyzed the temporal trend of ALT and permafrost temperature from 2006 to 2010. ALT is estimated as the maximum thaw depth in the late autumn, through linear interpolation of soil temperature profiles between two neighboring points above and below the $0^{\circ} \mathrm{C}$ isotherm at all sites (Wu et al., 2010). Because soil temperature monitoring at the QXR began in June 2005, ALT can be estimated from 2005 to 2010. The rate of change in ALT was estimated using linear regression, using $6 \mathrm{yr}$ of ALT data for each site with $P<0.05$. Annual mean permafrost temperature at the $6.0 \mathrm{~m}$ depth, and MAGT, were estimated using daily temperature data from 2006 to 2010. The rate of change in temperature was estimated using linear regression, using $5 \mathrm{yr}$ of temperature data for each site, with $P<0.05$.

\section{Variation of active layer thickness}

ALT on the QXP has a sensitive response to climate change (Jin et al., 2000; Zhao et al., 2000; Cheng and Wu, 2007; 
Table 2. Multi-year mean, maximum, minimum, and changing rate of active layer thickness along the QXR from 2006-2010.

\begin{tabular}{|c|c|c|c|c|c|}
\hline \multirow[b]{2}{*}{ Area } & \multirow[b]{2}{*}{$\begin{array}{l}\text { Site } \\
\text { name }\end{array}$} & \multicolumn{4}{|c|}{ Active layer thickness } \\
\hline & & $\begin{array}{r}\text { mean } \\
(\mathrm{m})\end{array}$ & $\begin{array}{r}\max \\
(\mathrm{m})\end{array}$ & $\begin{array}{r}\min \\
(\mathrm{m})\end{array}$ & $\begin{array}{r}\text { Rate of } \\
\text { change }\left(\mathrm{cm} \mathrm{a}^{-1}\right)\end{array}$ \\
\hline Kunlun Mts. & KM2 & 1.83 & 1.94 & 1.72 & $*$ \\
\hline Budongquan & BD1 & 2.47 & 2.66 & 2.40 & 4.30 \\
\hline \multirow[t]{4}{*}{ Chumaer River High Plain } & CM3 & 1.06 & 1.21 & 0.95 & 3.80 \\
\hline & CM5 & 2.84 & 2.89 & 2.75 & 1.20 \\
\hline & CM6 & 3.06 & 3.16 & 2.95 & -3.5 \\
\hline & CM7 & 4.80 & 4.84 & 4.73 & * \\
\hline \multirow[t]{2}{*}{ Kekexili Mts. } & WD3 & 1.93 & 2.46 & 1.74 & 3.4 \\
\hline & WD4 & 0.92 & 1.05 & 0.86 & 5.0 \\
\hline Hongliang River Basin & HR3 & 2.36 & 2.45 & 2.19 & 1.5 \\
\hline \multirow[t]{2}{*}{ Fenghuo Mt.s } & $\mathrm{FH} 2$ & 1.76 & 1.97 & 1.64 & 5.4 \\
\hline & FH3 & 4.01 & 4.14 & 3.94 & 4.1 \\
\hline \multirow[t]{2}{*}{ Yamaer River Basin } & YM1 & 3.32 & 3.70 & 3.02 & 8.7 \\
\hline & YM2 & 5.86 & 6.00 & 5.75 & 4.5 \\
\hline Wuli Basin & WL1 & 3.09 & 3.18 & 2.98 & * \\
\hline \multirow[t]{3}{*}{ Kaixinling Basin } & KL1 & 2.40 & 2.49 & 2.33 & 2.8 \\
\hline & KL3 & 2.83 & 2.92 & 2.74 & 2.0 \\
\hline & KL5 & 3.38 & 3.60 & 3.08 & 5.8 \\
\hline Tuotuo River Basin & TT1 & 2.60 & 2.76 & 2.44 & 4.3 \\
\hline \multirow[t]{2}{*}{ Wengquan Basin } & WQ1 & 4.65 & 4.84 & 4.44 & -6.8 \\
\hline & WQ2 & 3.36 & 3.50 & 3.13 & 3.7 \\
\hline \multirow[t]{3}{*}{ Tanggula Mts. } & TG2 & 4.99 & 5.50 & 4.44 & 19.9 \\
\hline & TG3 & 4.56 & 5.00 & 4.01 & 15.4 \\
\hline & TG4 & 2.77 & 2.88 & 2.49 & -5.2 \\
\hline \multirow[t]{2}{*}{ Zajiazangbu River Basin } & TJ1 & 3.50 & 4.68 & 3.43 & 4.90 \\
\hline & $\mathrm{TJ} 2$ & 3.42 & 3.48 & 3.31 & 1.74 \\
\hline Anduo Basin & AD2 & 2.37 & 2.47 & 2.29 & 3.70 \\
\hline
\end{tabular}

${ }^{*} P>0.05$

Zhao et al., 2008), and it changes consistently with changes in air temperature (Zhao et al., 2004, 2008; Wu and Zhang, 2010). Based on daily soil temperatures from the 27 sites, mean ALT varied from less than $1.1 \mathrm{~m}$ at the CM3 site to greater than $5.9 \mathrm{~m}$ at the YM2 site (Table 2). ALT from 2006 to 2010 along the QXR has experienced a significant interannual variation. ALT increased from 2006 to 2010 along the QXR, but ALT at sites CM6, WQ1, and TG4 decreased from 2006 to 2010 (Table 2). Except for this decrease, the ALT increase ranges from $1.2 \mathrm{~cm} \mathrm{a}^{-1}$ at site CM5 to $19.9 \mathrm{~cm} \mathrm{a}^{-1}$ at site TG2, with a mean rate of $6.3 \mathrm{~cm} \mathrm{a}^{-1}$, except at sites CM6, WQ1, and TG4 (Table 2). Continuous soil temperature monitoring data from the sites established in 1995/1998 indicated that ALT experienced a significant inter-annual variation from 1995 to 2010 (Fig. 2a), and the ALT increase ranges from $2.2 \mathrm{~cm} \mathrm{a}^{-1}$ to $16.12 \mathrm{~cm} \mathrm{a}^{-1}$, with a mean rate of $7.8 \mathrm{~cm} \mathrm{a}^{-1}$ (Fig. 2b), which is basically consistent with rate of change of ALT in the 27 sites along the QXR.

\section{Variation of permafrost temperatures}

Permafrost temperature at $6 \mathrm{~m}$ depth at six sites showed no variation (Table 3), with $P>0.05$. At the remaining sites, permafrost temperature at $6 \mathrm{~m}$ depth showed an increasing trend, ranging from $\sim 0.001{ }^{\circ} \mathrm{Ca} \mathrm{a}^{-1}$ at site TG 3 to $0.08^{\circ} \mathrm{C} \mathrm{a}^{-1}$ at site FH2, with a mean of $\sim 0.02^{\circ} \mathrm{Ca}^{-1}$ and $P<0.05$ (Ta-
Table 3. Multi-year mean, maximum, minimum, and changing rate of permafrost temperature at $6 \mathrm{~m}$ depth from 2006-2010.

\begin{tabular}{|c|c|c|c|c|c|}
\hline \multirow[b]{2}{*}{ Area } & \multirow[b]{2}{*}{$\begin{array}{l}\text { Site } \\
\text { name }\end{array}$} & \multicolumn{4}{|c|}{ Permafrost temperature at $6 \mathrm{~m}$ depth } \\
\hline & & $\begin{array}{r}\text { mean } \\
\left({ }^{\circ} \mathrm{C}\right)\end{array}$ & $\begin{array}{l}\max \\
\left({ }^{\circ} \mathrm{C}\right)\end{array}$ & $\begin{array}{r}\min \\
\left({ }^{\circ} \mathrm{C}\right)\end{array}$ & $\begin{array}{r}\text { Rate of } \\
\text { change }\left({ }^{\circ} \mathrm{Ca}^{-1}\right)\end{array}$ \\
\hline Kunlun Mts. & KM2 & -2.84 & -2.80 & -2.94 & -0.022 \\
\hline Budongquan & BD1 & -0.56 & -0.53 & -0.59 & 0.015 \\
\hline \multirow[t]{4}{*}{ Chumaer River High Plain } & $\mathrm{CM} 3$ & -1.53 & -1.49 & -1.56 & 0.017 \\
\hline & CM5 & -0.94 & -0.91 & -0.98 & 0.016 \\
\hline & CM6 & -0.70 & -0.68 & -0.72 & -0.007 \\
\hline & $\mathrm{CM} 7$ & -0.18 & -0.16 & -0.20 & 0.008 \\
\hline \multirow[t]{2}{*}{ Kekexili Mts. } & WD3 & -1.51 & & & * \\
\hline & WD4 & -2.59 & & & * \\
\hline Hongliang River Basin & HR3 & -0.87 & -0.82 & -0.95 & 0.029 \\
\hline \multirow[t]{2}{*}{ Fenghuo Mt.s } & $\mathrm{FH} 2$ & -1.86 & -1.66 & -2.01 & 0.080 \\
\hline & FH3 & -0.42 & -0.40 & -0.43 & 0.008 \\
\hline \multirow[t]{2}{*}{ Yamaer River Basin } & YM1 & -0.28 & -0.22 & -0.34 & 0.032 \\
\hline & YM2 & & & & * \\
\hline Wuli Basin & WL1 & -0.66 & -0.64 & -0.69 & 0.018 \\
\hline \multirow{3}{*}{ Kaixinling Basin } & KL1 & -0.66 & -0.63 & -0.68 & 0.012 \\
\hline & KL3 & -0.55 & -0.53 & -0.59 & 0.012 \\
\hline & KL5 & -0.38 & -0.33 & -0.45 & 0.029 \\
\hline \multirow[t]{2}{*}{ Tuotuo River Basin } & TT1 & -0.42 & & & * \\
\hline & TT2 & & & & * \\
\hline \multirow[t]{2}{*}{ Wengquan Basin } & WQ1 & -0.11 & -0.09 & -0.14 & 0.009 \\
\hline & WQ2 & -0.39 & & & * \\
\hline \multirow[t]{3}{*}{ Tanggula Mts. } & TG2 & -0.08 & -0.06 & -0.09 & 0.010 \\
\hline & TG3 & -0.12 & -0.12 & -0.13 & 0.001 \\
\hline & TG4 & -1.32 & & & * \\
\hline \multirow[t]{2}{*}{ Zajiazangbu River Basin } & $\mathrm{TJ} 1$ & -0.36 & -0.33 & -0.38 & 0.017 \\
\hline & $\mathrm{TJ} 2$ & -0.26 & -0.22 & -0.30 & 0.020 \\
\hline Anduo Basin & AD2 & -0.29 & -0.27 & -0.30 & 0.006 \\
\hline
\end{tabular}

* $P>0.05$

ble 3). Over mountain areas, permafrost temperature variation at $6 \mathrm{~m}$ depth is a complicated process that exhibits a decreasing trend, with a decreasing rate of $-0.022^{\circ} \mathrm{Ca}^{-1}$ at site $\mathrm{KM} 2$, but an increasing trend at site $\mathrm{FH} 2$, with an increasing rate of $0.08^{\circ} \mathrm{Ca}^{-1}$. At sites WD3 and WD4, there is no trend in permafrost temperatures at $6 \mathrm{~m}$ depth (Table 3 ). In high-plain and basin environments, permafrost temperature at $6 \mathrm{~m}$ depth shows an increasing trend, except at site CM6, ranging from less than $0.001{ }^{\circ} \mathrm{Ca}^{-1}$ at site TG3 to greater than $0.049^{\circ} \mathrm{Ca}^{-1}$ at site WL1, with a mean of $0.016^{\circ} \mathrm{Ca}^{-1}$; less than the mean increase of all sites.

Permafrost soil temperature at the monitoring sites established in 1995 and 1998 indicates that permafrost temperature at $6 \mathrm{~m}$ depth experienced a significant inter-annual variation from 1995 to 2010 (Fig. 3a), and permafrost temperature rose from $0.008^{\circ} \mathrm{Ca}^{-1}$ at site TG1 to $0.055^{\circ} \mathrm{Ca}^{-1}$ at site FH1, with a mean rate of $0.029^{\circ} \mathrm{Ca}^{-1}$ (Fig. 3b), which is consistent with rate of permafrost temperature change at $6.0 \mathrm{~m}$ depth in the 27 sites along the QXR.

MAGT shows an increasing trend, ranging from less than $0.001{ }^{\circ} \mathrm{Ca}^{-1}$ at the site of AD2 to greater than $0.06^{\circ} \mathrm{Ca}^{-1}$ at site $\mathrm{FH} 2$, with a mean of $0.012{ }^{\circ} \mathrm{Ca}^{-1}$ (Table 4). However, rate of increase of MAGT in mountain areas is much higher than in high-plain and basin areas, ranging from $0.003^{\circ} \mathrm{Ca}^{-1}$ at site WD3 to $0.06^{\circ} \mathrm{Ca}^{-1}$ at site $\mathrm{FH} 2$, with a mean of $0.026^{\circ} \mathrm{Ca}^{-1}$ (Table 4). Over high plains and basins, the rate of MAGT change ranged from $0.001{ }^{\circ} \mathrm{Ca}^{-1}$ at site AD1 to 
Table 4. Multi-year mean, maximum, minimum, and changing rate of mean annual ground temperature from 2006-2010.

\begin{tabular}{|c|c|c|c|c|c|}
\hline \multirow[b]{2}{*}{ Area } & \multirow[b]{2}{*}{$\begin{array}{l}\text { Site } \\
\text { name }\end{array}$} & \multicolumn{4}{|c|}{ MAGT at depth of 12 to $15 \mathrm{~m}$} \\
\hline & & $\begin{array}{r}\text { mean } \\
\left({ }^{\circ} \mathrm{C}\right)\end{array}$ & $\begin{array}{l}\max \\
\left({ }^{\circ} \mathrm{C}\right)\end{array}$ & $\begin{array}{r}\min \\
\left({ }^{\circ} \mathrm{C}\right)\end{array}$ & $\begin{array}{r}\text { Rate of } \\
\text { change }\left({ }^{\circ} \mathrm{Ca}^{-1}\right)\end{array}$ \\
\hline Kunlun Mts. & KM2 & -3.04 & -2.99 & -3.1 & 0.027 \\
\hline Budongquan & BD1 & -0.60 & -0.61 & -0.58 & 0.007 \\
\hline \multirow[t]{4}{*}{ Chumaer River High Plain } & CM3 & -1.20 & -1.19 & -1.21 & 0.004 \\
\hline & CM5 & -1.20 & -1.16 & -1.23 & 0.016 \\
\hline & CM6 & -0.95 & -0.94 & -0.97 & -0.003 \\
\hline & $\mathrm{CM} 7$ & -0.41 & -0.38 & -0.44 & 0.014 \\
\hline \multirow[t]{2}{*}{ Kekexili Mts. } & WD3 & -1.53 & -1.50 & -1.57 & 0.017 \\
\hline & WD4 & -2.56 & -2.50 & -2.61 & 0.025 \\
\hline Hongliang River Basin & HR3 & -1.11 & -1.06 & -1.19 & 0.03 \\
\hline \multirow[t]{2}{*}{ Fenghuo Mt.s } & $\mathrm{FH} 2$ & -2.02 & -1.9 & -2.16 & 0.06 \\
\hline & FH3 & -0.65 & -0.64 & -0.67 & 0.003 \\
\hline \multirow[t]{2}{*}{ Yamaer River Basin } & YM1 & -0.39 & -0.37 & -0.41 & 0.012 \\
\hline & YM2 & -0.25 & -0.20 & -0.34 & 0.029 \\
\hline Wuli Basin & WL1 & -0.63 & -0.63 & -0.64 & 0.003 \\
\hline \multirow{3}{*}{ Kaixinling Basin } & KL1 & -0.69 & -0.67 & -0.71 & 0.009 \\
\hline & KL3 & -0.72 & -0.7 & -0.74 & 0.009 \\
\hline & KL5 & -0.60 & -0.58 & -0.63 & 0.012 \\
\hline \multirow{2}{*}{ Tuotuo River Basin } & TT1 & -0.33 & -0.32 & -0.33 & 0.003 \\
\hline & TT2 & 0.16 & 0.17 & 0.16 & 0.004 \\
\hline \multirow[t]{2}{*}{ Wengquan Basin } & WQ1 & -0.09 & -0.08 & -0.1 & 0.003 \\
\hline & WQ2 & -0.32 & -0.29 & -0.36 & 0.029 \\
\hline \multirow[t]{3}{*}{ Tanggula Mts. } & TG2 & 0.71 & & & * \\
\hline & TG3 & 0.27 & 0.27 & 0.26 & 0.003 \\
\hline & TG4 & -1.15 & -1.13 & -1.16 & 0.004 \\
\hline \multirow{2}{*}{ Zajiazangbu River Basin } & $\mathrm{TJ} 1$ & -0.06 & & & $*$ \\
\hline & $\mathrm{TJ} 2$ & -0.08 & -0.09 & -0.06 & 0.007 \\
\hline Anduo Basin & AD2 & -0.08 & -0.08 & -0.09 & 0.001 \\
\hline
\end{tabular}

* $P>0.05$

$0.029^{\circ} \mathrm{Ca}^{-1}$ at site YM2, with a mean of $0.008^{\circ} \mathrm{Ca}^{-1}$ (Table 4$)$.

\section{Discussions and conclusions}

This study examined variation of ALT, permafrost temperature at $6 \mathrm{~m}$ depth, and MAGT along the QXR, using daily soil and permafrost temperature measurements from 2006 to 2010. Our results show that ALT and permafrost temperatures have extensive temporal and spatial differences along the QXR.

Based on data from 27 sites over $5 \mathrm{yr}$ along the QXR, mean ALT is $\sim 3.1 \mathrm{~m}$, with a range of 1.1 to $5.9 \mathrm{~m}$. Except for the thinning of the active layer at sites CM6, WQ1, and TG4, the mean rate of ALT increase is $\sim 6.3 \mathrm{~cm} \mathrm{a}^{-1}$, with a range from 1.2 to $19.9 \mathrm{~cm} \mathrm{a}^{-1}$. The mean permafrost temperature at $6 \mathrm{~m}$ depth is $\sim-0.76^{\circ} \mathrm{C}$, with a range from -0.08 to $-2.84^{\circ} \mathrm{C}$. Except for the lower permafrost temperature at sites $\mathrm{KM} 1$ and $\mathrm{CM} 6$, the mean rate of permafrost temperature rise is $\sim 0.02{ }^{\circ} \mathrm{C} \mathrm{a}^{-1}$, with a range from 0.001 to $0.08^{\circ} \mathrm{C} \mathrm{a}^{-1}$. The mean MAGT is $\sim-0.82^{\circ} \mathrm{C}$, with a range of -0.06 to $-3.04{ }^{\circ} \mathrm{C}$. The mean rate of MAGT rise is $\sim 0.012{ }^{\circ} \mathrm{Ca}^{-1}$, with a range of 0.001 to $0.06{ }^{\circ} \mathrm{Ca}^{-1}$. The variation in the thermal state of cold permafrost with a MAGT lower than $-1.0^{\circ} \mathrm{C}$ is larger than that of warm permafrost with a MAGT higher than $-1.0^{\circ} \mathrm{C}$. The decrease of ALT at sites CM6,

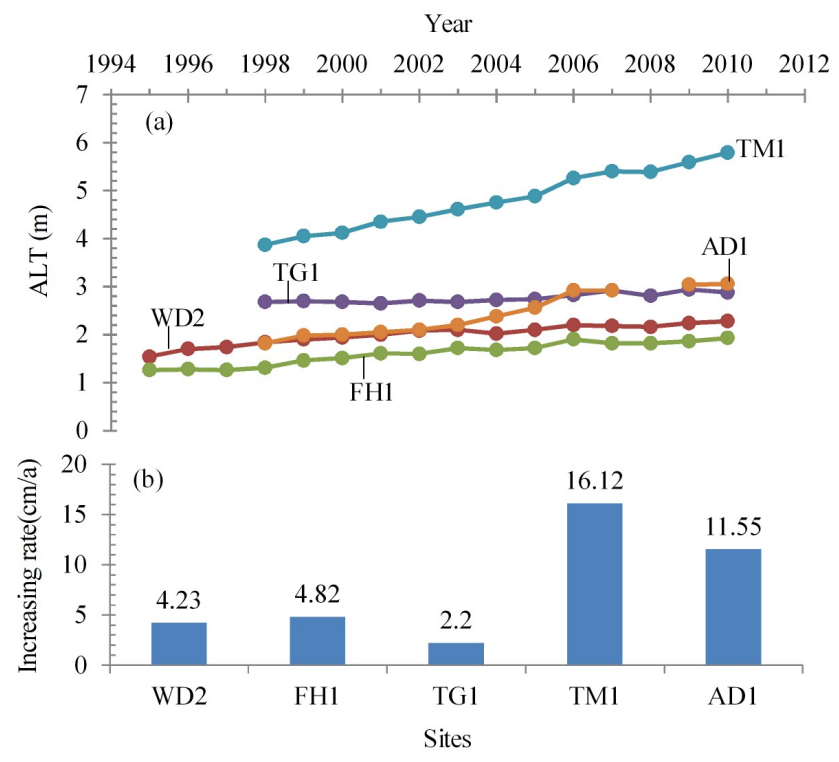

Fig. 2. Active layer thickness (ALT) along the Qinghai-Xizang (Tibet) Highway. (a) ALT. (b) Increasing rate of ALT. The increasing rate was estimated using linear regression for each site using $10 \mathrm{yr}$ of ALT data with $P<0.05$.

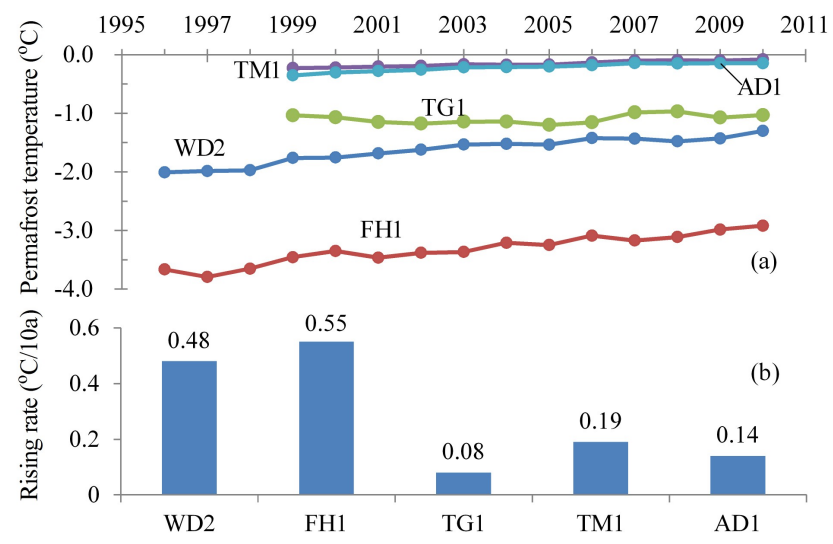

Fig. 3. Variation of permafrost temperature at $6 \mathrm{~m}$ depth along the Qinghai-Xizang (Tibet) Highway. (a) Variation of permafrost temperature at $6 \mathrm{~m}$ depth. (b) Rate of permafrost temperature change at $6 \mathrm{~m}$ depth. The rate of permafrost temperature change was estimated using linear regression, with $P<0.05$.

WQ1, and TG4 may depend upon local effects, but we cannot explain which factors control the decreasing ALT.

It is widely hypothesized that ALT and permafrost temperature will increase in response to climate warming. Such a response may be complex; however, the seasonality changes in air temperature change may be predominant in the ALT and permafrost temperature variations over the QXP (Wu and Zhang, 2010). ALT variation is in disaccord with fluctuations in permafrost temperature at the different depths. These differences may indicate that local factors may control ALT and permafrost temperature variation at the local scale. 
Although climate warming results in rising permafrost temperature and increasing ALT (Wang et al., 2000; Cheng and $\mathrm{Wu}, 2007$; Wu and Zhang, 2008; Wu and Zhang, 2010), local factors control the variation of permafrost temperature and ALT, creating spatial and temporal change discordances under the effects of climate change. Spatial and temporal changes in permafrost will result from varying feedbacks of permafrost change to climate change. Therefore, further studies are required into the features and mechanics of permafrost under the effects of local factors, and the relationships between permafrost and climate change.

Acknowledgements. This work was supported by the Global Change Research Program of China (grant 2010CB951402), and the Program for Innovative Research Group of the Natural Science Foundation of China (grant 41121061), and the project (grant Y02C671001).

Edited by: S. Gruber

\section{References}

Cheng, G. D.: Application of thermistor in measuring permafrost temperature, Journal of Glaciology and Geocryology, 2, 66-68, 1980 (in Chinese).

Cheng, G. D.: A roadbed cooling approach for the construction of Qinghai-Tibet Railway, Cold Reg. Sci. Technol., 42, 169-176, 2005.

Cheng, G. and Wu, T.: Responses of permafrost to climate change and their environmental significance, QinghaiXizang (Tibet) Plateau, J. Geophys. Res., 112, F02S03, doi:10.1029/2006JF000631, 2007.

Cheng, G. D., Lai, Y., Sun, Z., and Jiang, F.: The "thermal semiconductor" effect of crushed rocks, Permafrost Periglac. Processes, 18, 151-160, 2007.

Jin, H. J., Li, S. X., Cheng, G. D., Wang, S. L., and Li, X.: Permafrost and climate change in China, Global Planet. Change, 26, 387-404, 2000.

Liu, X. D. and Chen, B. D.:Warming in the Tibetan Plateau during recent decades, Int. J. Climatol., 20, 1729-1742, 2000.

Nan, Z. T., Li, S. X., and Cheng, G. D.: Prediction of permafrost distribution on Qinghai-Tibet Plateau in the next 50 and 100 years, Sci. China Ser. D, 48, 797-804, 2005.

Sheng, Y., Zhang, J., and Liu, Y.: Thermal regime in the embankment of Qinghai-Tibetan highway in permafrost regions, Cold Reg. Sci. Technol., 35, 35-44, 2002.

Wang, S. L., Jin, H. J., Li, S. X., and Zhao, L.: Permafrost degradation on the Qinghai-Xizang (Tibet) Plateau and its environmental impacts, Permafrost Periglac. Process, 11, 43-53, 2000.
Wu, Q. B. and Liu, Y. Z.: Ground temperature monitoring and its recent change in Qinghai Tibet Plateau, Cold Reg. Sci. Technol., 38, 85-92, 2004.

Wu, Q. and Zhang, T.: Recent Permafrost Warming on the Qinghai-Tibetan Plateau, J. Geophys. Res., 11, D13108, doi:10.1029/2007JD009539, 2008.

Wu, Q. and Zhang, T.: Changes in Active Layer Thickness over the Qinghai-Tibetan Plateau from 1995-2007, J. Geophys. Res., 115, D09107, doi:10.1029/2009JD012974, 2010.

Wu, Q. B., Liu, Y., and Yu, H.: Monitoring Network of the Permafrost Conditions and Embankment Performance along the Qinghai-Tibet Railway, Proceedings of 9th International Conference on Permafrost, 1963-1968, 2008.

Wu, Q. B., Zhang, Z., and Liu, Y.: Long-term thermal effect of asphalt pavement on permafrost under embankment, Cold Reg. Sci. Technol., 60, 221-229, 2010.

Zhang, T., Barry, R. G., Knowles, K., Heginbottom, J. A., and Brown, J.: Statistics and characteristics of permafrost and ground-ice distribution in the Northern Hemisphere, Polar Geogr., 23, 132-154, 1999.

Zhang, T., Barry, R. G., Knowles, K., Ling, F., and Armstrong, R.: Distribution of seasonally and perennially frozen ground in the Northern Hemisphere, in: Proceedings: The 8th International Conference on Permafrost, 21-25 July 2003, Zurich, Switzerland vol. 2, edited by: Phillips, M., Springman, S. M., and Arenson, L. U., A.A. Balkema, Brookfield, Vt., 1289-1294, 2003.

Zhang, T., Baker, H. W.,Cheng, G. D., and Wu, Q. B.: The QinghaiTibet Railroad: A milestone project and its environmental impact, Cold Reg. Sci. Technol., 53, 229-240, 2008.

Zhao, L., Cheng, G., and Li, S.: Thawing and freezing processes of active layer in Wudaoliang region of Tibetan Plateau, Chinese Sci. Bull., 45, 2181-2186, 2000.

Zhao, L., Ping, C., Yang, D., Cheng, G., Ding, Y., and Liu, S.: Changes of climate and seasonally frozen ground over the past 30 years in Qinghai-Xizang (Tibetan) Plateau, China. Global Planet. Change, 43, 19-31, 2004.

Zhao, L., Wu, T., Yongjian, D., and Changwei, X.: Monitoring permafrost changes on the Qinghai-Tibet Plateau, in: Extended Abstracts, Proceedings of the Ninth International Conference on Permafrost, vol. 2, edited by: Kane D. L and Hinkel, K. M., Institute of Northern Engineering, University of Alaska, Fairbanks, Alaska, 2071-2076, 2008.

Zhao, L., Wu, Q. B., Marchenko, S. S., and Sharkhuu, N.: Thermal state of Permafrost and active layer in Central Asia during the International Polar Year, Permafrost and Periglac. Process, 21, 198-207, 2010.

Zhou, Y.-W., Guo, D.-X., Qiu, G.-Q., Cheng, G.-D., and Li, S.-D.: Geocryology in China, Science Press, Beijing, 450 pp., 2000 (in Chinese). 